\title{
Hemolytic Activity of a Dental Adhesive Monomer (N-methacryloyloxy-5-aminosalicylic acid, MASA) and its Interaction with Phospholipid Liposomes as Studied by NMR and DSC
}

\author{
Seiichiro FUJISAWA, Yasuo KOMODA* and Yoshinori KADOMA* \\ Faculty of Dentistry, Tokyo Medical and Dental University, 1-5-45, Yushima, Bunkyou-Ku, Tokyo, 113 \\ Japan and*Institute for Medical and Dental Engineering, Tokyo Medical and Dental University, 2-3-10, \\ Kanda-Surugadai, Chiyoda-Ku, Tokyo, 101 Japan
}

Received on January 16, 1992

Accepted on March 3, 1992

$\mathrm{N}$-methacryloyloxy-5-aminosalicylic acid (MASA) has recently been used as an adhesive primer in restorative resin systems. To monitor the biological activity of MASA, we studied changes in NMRchemical shifts $\left(\delta_{\mathrm{H}}\right)$ and the differential scanning calorimetry (DSC) phase transition temperature (Tm) of dipalmitoylphosphatidylcholine (DPPC)/MASA liposomes with or without the presence of albumin and collagen. The $\delta_{\mathrm{H}}$ and the Tm did not alter significantly and the interaction of MASA with DPPC was found to be small. Hemolytic activity of MASA was markedly smaller than that of the phosphate monomer (MDP) in bonding agents widely used. These findings suggest that using a MASA primer in resin systems has an acceptable biocompatibility for dentin-pulp, involving its adsorption and adhesion to hard tooth tissues.

Key words : MASA, Hemolysis, Phospholipid liposomes

\section{INTRODUCTION}

Monomers with carboxylic acid are particularly effective in promoting adsorption and adhesion to cationic surfaces such as the hydroxyapatite in hard tooth tissues ${ }^{1-4)}$. Chelating agents containing the polymerizable methacrylate group have been synthesized, and the ability of $\mathrm{N}$-methacryloyloxy-5-aminosalicylic acid (MASA) to promote adhesion between resin system and hard tooth tissues has been studied. The methacrylate group is considered to have a proven sedative effect on pulp, since they are derived from salicylic acid ${ }^{5}$. Recently, MASA has been used as an adhesive primer due to its strong bond between resin and dentin. In clinical applications, a desensitizing effect on hypersensitive dentin has been suggested ${ }^{6}$. Thus, an adhesive MASA primer has been applied to the resin restorative system with an acceptable pulpal response and clinical performance ${ }^{7,8}$.

To clarify the mechanism of interaction of dental adhesive monomers on biological membranes at a molecular level, we have intensively investigated their interaction with human erythrocytes and with phospholipid liposomes that used as a model for biomembranes $^{9,10}$. NMR and differential scanning calorimeter (DSC) findings are used to interpret the degree and nature of biological activities caused by the action of monomers ${ }^{9,10)}$.

In the present study, we examined the degree of hemolytic activity caused by MASA as compared with methacryloyloxydecyl dihydrogenphosphate (MDP). Changes in the $\delta_{\mathrm{H}}$ and the phase transition temperature $(\mathrm{Tm})$ of $\mathrm{L}$ - $\alpha$-dipalmitoylphosphatidylcholine (DPPC)/ MASA liposomes with or without the presence of albumin (or collagen) in $\mathrm{D}_{2} \mathrm{O}$ and/or a $\mathrm{D}_{2}$ 
O buffer solution were also studied.

\section{MATERIALS AND METHODS}

L- $\alpha$-dipalmitoylphosphatidylcholine $\quad(\mathrm{DPPC})^{*}$ cholesterol $(\mathrm{CS})^{*} 3$-(trimethylsilyl) propionic acid sodium salts- $\mathrm{d}_{4}\left(\right.$ TMSPA)**, dimethylsulfoxide- $\mathrm{d}_{6}(\mathrm{DMSO})^{* *}$, deuterium oxide $\left(\mathrm{D}_{2} \mathrm{O}\right)^{* *}, \mathrm{KD}_{2} \mathrm{PO}_{4}{ }^{+}$, and $40 \% \mathrm{NaOD}^{* *}$ were used without further purification. $\mathrm{N}$ methacryloyloxy-5-aminosalicylic acid (MASA) was a gift and was used without further purification. Chemical structure of MASA, DPPC and their numbering systems are shown in Fig. 1. ${ }^{1} \mathrm{H}-\mathrm{NMR}$ of MASA in DMSO- $\mathrm{d}_{6}$ (The $\delta_{\mathrm{H}}$ values are in ppm up- and downfield from DMSO $-\mathrm{d}_{6}\left(\delta_{\mathrm{H}}=2.50 \mathrm{ppm}\right) \delta_{\mathrm{H}}: 1.94\left(3 \mathrm{H}, \mathrm{s}, 2-\mathrm{CH}_{3}\right), 5.47(1 \mathrm{H}$ broad s, $1 \mathrm{Ha}), 5.80(1 \mathrm{H}$,broad s, $1 \mathrm{Hb}), 6.90\left(1 \mathrm{H}, \mathrm{d}, \mathrm{J}=9.2 \mathrm{~Hz}, 5^{\prime} \mathrm{H}\right), 7.77\left(1 \mathrm{H}\right.$, double $\mathrm{d}, \mathrm{J}=9.2$ and $\left.2.4 \mathrm{~Hz}, 6^{\prime} \mathrm{H}\right), 8.16(1 \mathrm{H}, \mathrm{d}, \mathrm{J}=$ $\left.2.4 \mathrm{H}_{\mathrm{z}}, 2^{\prime} \mathrm{H}\right)$, and $\left.9.72(1 \mathrm{H}, \mathrm{s}, \mathrm{NH})\right)$

Albumin (Human, Fraction V, powder) ${ }^{++}$and collagen (Type VII, acid soluble from rat tail)* were used without further purification.

The preparation of liposomes, NMR, DSC and hemolysis studies, were identical to those described in our previous papers ${ }^{9,10)}$. The preparation of a $\mathrm{D}_{2} \mathrm{O}$ buffer solution is as follws.

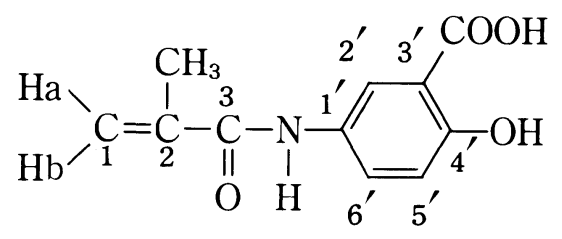

MASA

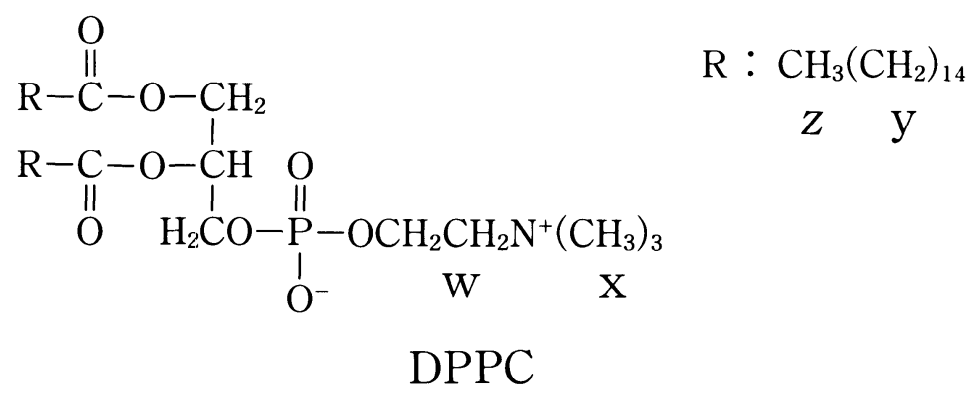

Fig. 1 Structure of MASA (N-methacryloyloxy-5-aminosalicylic acid) and DPPC (dipalmitoylphosphatidylcholine), Numbering and small alphabets described for NMR-assignment.

* Sigma Chemical Co., St. Louis, MO, USA. ${ }^{* *}$ Merck Chemical Co., Darmstadt, Germany.

+ Kanto Chemical Co., Tokyo, Japan.

++ Tokyo Kasei Chemical Co., Tokyo, Japan. 
A solution of $0.1 \mathrm{M} \mathrm{KD} \mathrm{KD}_{2} \mathrm{PO}_{4}-\mathrm{D}_{2} \mathrm{O}$ was adjusted to $\mathrm{pH} 7.03$ by addition of $40 \% \mathrm{NaOD}-\mathrm{D}_{2} \mathrm{O}$ solution.

The methyl methacrylate (MMA) and methacryloyloxydecyl dihydrogenphosphate (MDP) used were the same as previously described in this journal ${ }^{9}$.

\section{RESULTS AND DISCUSSION}

\section{NMR studies of DPPC/MASA liposomes in a buffer solution}

The ${ }^{1} \mathrm{H}-\mathrm{NMR}$ spectra of DPPC liposomes and DPPC/MASA (1:1 molar ratio) liposomes at $52^{\circ} \mathrm{C}$, and their chemical shifts $\left(\delta_{\mathrm{H}}\right)$ and chemical shift differences $\left(\Delta \delta_{\mathrm{H}}\right)$ at $30^{\circ} \mathrm{C}$ and $52^{\circ} \mathrm{C}$ in $\mathrm{D}_{2} \mathrm{O}$ buffer solution at $\mathrm{pH} 7.03$ are shown in Fig. 2 and Table 1, respectively. Since the spectrum of MASA in DPPC bilayers at $30^{\circ} \mathrm{C}$ was similar to that at $52^{\circ} \mathrm{C}$, only that at $52^{\circ}$ $\mathrm{C}$ is shown in Fig. 2. The phase transition temperature (Tm) of DPPC/MASA (1:1 molar ratio) liposomes and DPPC liposomes were $35^{\circ} \mathrm{C}$ and $40.5^{\circ} \mathrm{C}$, respectively (see Table 4). From this, it was found that DPPC/MASA liposomes are in a liquid phase at $52^{\circ} \mathrm{C}$, above the $\mathrm{Tm}$. Signals of the choline $\mathrm{N}$-methyl $(\mathrm{x})$, the methylene in acyl chains $(\mathrm{y})$, and the terminal methyl (z) group due to DPPC were observed in both DPPC and DPPC/MASA liposomes. Except for those groups, a signal from the N-methylene group (w) was newly observed in DPPC /

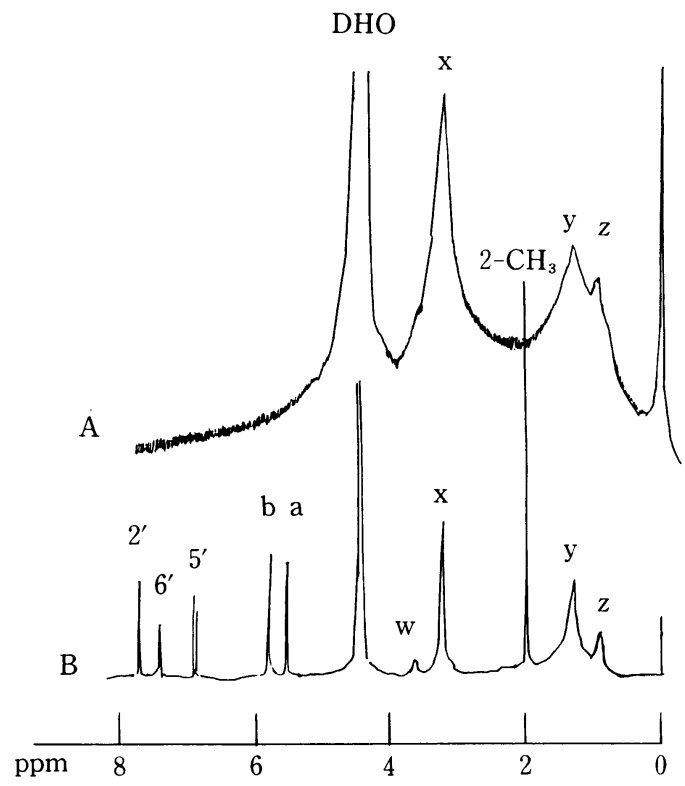

Fig. $2{ }^{1} \mathrm{H}-\mathrm{NMR}$ spectra of DPPC liposomes and DPPC/MASA liposomes in $\mathrm{D}_{2} \mathrm{O}$ buffer solution at $\mathrm{pH} 7.03$ at $52^{\circ} \mathrm{C}$.

A : DPPC liposomes, B : DPPC/MASA (1:1 molar ratio) liposomes and numbering: see Fig. 1. 
Table $1{ }^{1} \mathrm{H}-\mathrm{NMR}$ chemical shifts $\left(\delta_{\mathrm{H}}\right)$ and chemical shift difference $\left(\Delta \delta_{\mathrm{H}}\right)$ of $\mathrm{N}$-methacryloyloxy-5 -aminosalicylic acid (MASA) and dipalmitoylphosphatidylcholine (DPPC) in DPPC/MASA (1 : 1 , molar ratio) liposomes in $\mathrm{D}_{2} \mathrm{O}$ buffer solution at $\mathrm{pH} 7.03$.

\begin{tabular}{|c|c|c|c|c|c|c|c|}
\hline \multirow{3}{*}{ Proton Nos. } & \multicolumn{2}{|c|}{ MASA } & \multicolumn{2}{|c|}{ DPPC/MASA } & \multirow[b]{2}{*}{$\Delta \delta_{\mathrm{H}}$} & \multirow[b]{2}{*}{$\Delta \delta_{\mathrm{H}}$} & \multirow[b]{2}{*}{$\Delta \delta_{\mathrm{H}}$} \\
\hline & $30^{\circ} \mathrm{C}$ & $52^{\circ} \mathrm{C}$ & $30^{\circ} \mathrm{C}$ & $52^{\circ} \mathrm{C}$ & & & \\
\hline & A & B & $\mathrm{C}$ & $\mathrm{D}$ & $\mathrm{C}-\mathrm{A}$ & $\mathrm{D}-\mathrm{B}$ & D-E \\
\hline $2 \mathrm{CH}_{3}$ & $1.99 \mathrm{~m}$ & $2.00 \mathrm{~m}$ & 1.99 & 2.00 & 0.00 & 0.00 & \\
\hline $1 \mathrm{Ha}$ & $5.54 \mathrm{brs}$ & $5.54 \mathrm{brs}$ & 5.54 & 5.54 & 0.00 & 0.00 & \\
\hline $1 \mathrm{Hb}$ & $5.80 \mathrm{brs}$ & $5.80 \mathrm{brs}$ & 5.80 & 5.81 & 0.00 & 0.01 & \\
\hline $5^{\prime} \mathrm{H}$ & $6.93 \mathrm{~d}^{*}$ & $6.94 \mathrm{~d}^{\#}$ & 6.93 & 6.93 & 0.00 & 0.00 & \\
\hline $6^{\prime} \mathrm{H}$ & $7.44 \mathrm{dd} * *$ & $7.45 \mathrm{dd}^{\# \#}$ & 7.44 & 7.46 & 0.00 & 0.01 & \\
\hline $2^{\prime} \mathrm{H}$ & $7.74 \mathrm{~d} * * *$ & $7.76 \mathrm{~d}^{\# \# \# ~ \# ~}$ & 7.74 & 7.76 & 0.00 & 0.00 & \\
\hline w $\mathrm{NCH}_{2}$ & & & NS & 3.67 & & & - \\
\hline $\mathrm{x} \mathrm{N} \mathrm{N}^{+}\left(\mathrm{CH}_{3}\right)_{3}$ & & & & 3.24 & & & -0.03 \\
\hline $\mathrm{y}\left(\mathrm{CH}_{2}\right)_{14}$ & & & NS & 1.30 & & & 0.00 \\
\hline $\mathrm{z} \mathrm{CH}_{3}$ & & & NS & 0.91 & & & 0.00 \\
\hline
\end{tabular}

The $\delta_{\mathrm{H}}$ value is ppm downfield from TMSPA as used an external reference in $\mathrm{D}_{2} \mathrm{O}$ buffer solution. Proton Nos and alphabets $(\mathrm{w}-\mathrm{z})$ : see Fig. 1, $\mathrm{m}$ : multiplet, brs : broad singlet, d : doublet, dd : double doublet, $*: \mathrm{J}=8.6 \mathrm{~Hz}, * *: \mathrm{J}=2.6 \mathrm{~Hz}$ and $8.6 \mathrm{~Hz}, * * *: \mathrm{J}=2.6 \mathrm{~Hz}, \#: \mathrm{J}=8.9 \mathrm{~Hz}$, \#\# : J=2.6Hz and $\mathrm{J}=8.9 \mathrm{~Hz}$, \#\#: $\mathrm{J}=2.6 \mathrm{~Hz}$, NS : no signal, E : DPPC liposomes.

MASA liposomes (see Fig. 2), indicating that the phosphodiester group $(\mathrm{O}-\mathrm{C}-\mathrm{C}-\mathrm{N}$ bond) in DPPC was affected by MASA. As an observation consistent with the suggestion, we know a large interaction of MDP with the phosphodiester group ${ }^{9}$, since the phosphodiester group in DPPC serves as an $\mathrm{H}$-bond acceptor ${ }^{11}$. As shown schematically in Fig. 1, the hydrogen bond between carbonate ions and $\mathrm{OH}$ groups in MASA is formed in water and there by $\mathrm{H}^{+}$ allowing MASA to easily affect the phosphodiester group (O-C-C-N bond) in DPPC bilayers. However, as shown in Table 1 , the $\delta_{\mathrm{H}}$ values $\left(2-\mathrm{CH}_{3}, 1 \mathrm{Ha}, 1 \mathrm{Hb}, 5^{\prime} \mathrm{H}, 2^{\prime} \mathrm{H}\right.$, and $\left.6^{\prime} \mathrm{H}\right)$ at $30^{\circ} \mathrm{C}$ were $0.00 \mathrm{ppm}$ and those at $52^{\circ} \mathrm{C}$ were $0.00-0.01 \mathrm{ppm}$, indicating that MASA in the DPPC bilayers is non-shielding and therefore, located in a region close to the surface at both $30^{\circ} \mathrm{C}$ and $52^{\circ} \mathrm{C}$. The interaction of MASA with the DPPC bilayer at $\mathrm{pH} 7.03$ were considered weak.

NMR studies of DPPC/CS/MASA liposomes in $\mathrm{D}_{2} \mathrm{O}$ The ${ }^{1} \mathrm{H}-\mathrm{NMR}$ spectra of DPPC/ CS/MASA (4: 1:2 molar ratio) liposomes (A) and MASA (B) and $\delta_{\mathrm{H}}$ and $\Delta \delta_{\mathrm{H}}$ value of their signals in $\mathrm{D}_{2} \mathrm{O}$ are shown in Fig. 3 and Table 2, respectively. As shown in Fig. 3 at $30^{\circ} \mathrm{C}$, signals in A due to the $2-\mathrm{CH}_{3}, 1 \mathrm{Ha}, 1 \mathrm{Hb}, 5^{\prime} \mathrm{H}, 6^{\prime} \mathrm{H}$ and $2^{\prime} \mathrm{H}$ of MASA were markedly broader than those of MASA in B. Signals due to the $\mathrm{x}, \mathrm{y}$, and $z$ groups of DPPC disappeared. As shown in Table 2, downfield shifts occurred for $1 \mathrm{Hb}, 2^{\prime} \mathrm{H}, 5^{\prime} \mathrm{H}$ and $6^{\prime} \mathrm{H}$ both at $30^{\circ} \mathrm{C}$ and $52^{\circ}$ C. The $\Delta \delta_{\mathrm{H}}$ values of $2^{\prime} \mathrm{H}$ and $6^{\prime} \mathrm{H}$ were $0.06-0.07$ and $0.06-0.13 \mathrm{ppm}$, respectively and those of $2 \mathrm{CH}_{3}, 1 \mathrm{Ha}, 1 \mathrm{Hb}$, and $5^{\prime} \mathrm{H}$ was $0.00-0.02 \mathrm{ppm}$. Large significant downfield shifts occurred for $2^{\prime} \mathrm{H}$ and $6^{\prime} \mathrm{H}$. The $\Delta \delta_{\mathrm{H}}$ values of MASA in DPPC/MASA (1: 1 molar ratio) without CS in $\mathrm{D}_{2} \mathrm{O}$ were also determined, indicating that large downfield shifts $(0.12-0.23 \mathrm{ppm})$ occurred for $2^{\prime} \mathrm{H}$ and $6^{\prime} \mathrm{H}$. The $\Delta \delta_{\mathrm{H}}$ values of MASA in DPPC/MASA (1: 1 molar ratio) without CS in $\mathrm{D}_{2} \mathrm{O}$ were also determined, indicating that large downfield shifts $(0.12-0.23 \mathrm{ppm})$ occurred for $2^{\prime} \mathrm{H}$ and $6^{\prime} \mathrm{H}$ (data not shown). This indicates that the $2^{\prime} \mathrm{H}$ and $6^{\prime} \mathrm{H}$ moiety is probably located on the surface of the liposomes without being incorporated into the acyl chains of 


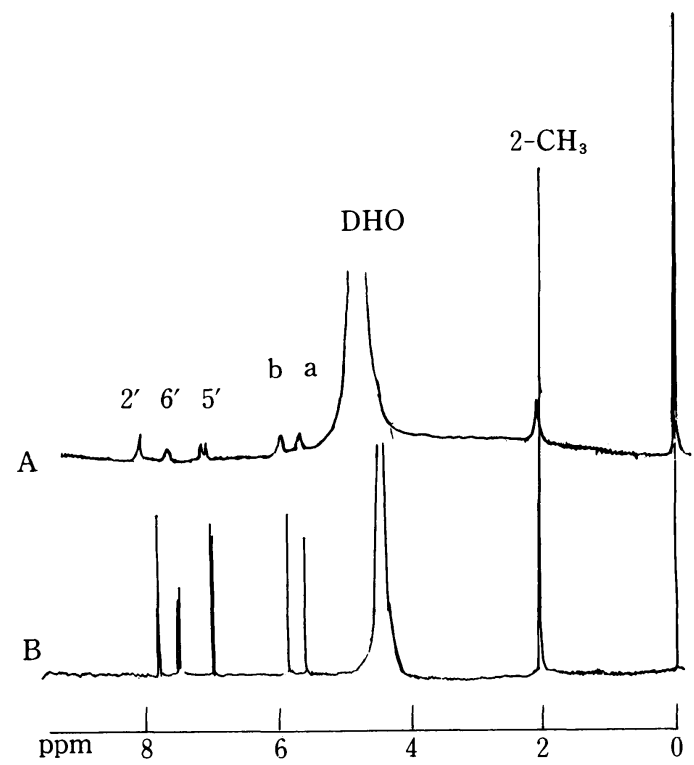

Fig. $3{ }^{1} \mathrm{H}-\mathrm{NMR}$ spectra and DPPC/CS/MASA liposomes in $\mathrm{D}_{2} \mathrm{O}$ at $30^{\circ} \mathrm{C}$.

A : DPPC/CS/MASA (4:1:2 molar ratio) liposomes, B : MASA and numbering: see Fig. 1.

Table $2 \quad{ }^{1} \mathrm{H}$-NMR chemical shifts $\left(\delta_{\mathrm{H}}\right)$ and chemical shift difference $\left(\Delta \delta_{\mathrm{H}}\right)$ of $\mathrm{N}$-methacryloyloxy-5-aminosalicylic acid (MASA) in DPPC/CS/MASA $(4: 1: 2$ molar ratio) liposomes in $\mathrm{D}_{2} \mathrm{O}$.

\begin{tabular}{|c|c|c|c|c|c|c|}
\hline \multirow{3}{*}{ Proton Nos. } & \multicolumn{2}{|c|}{ MASA } & \multicolumn{2}{|c|}{ DPPC/CS/MASA } & \multirow[b]{2}{*}{$\Delta \delta_{\mathrm{H}}$} & \multirow[b]{2}{*}{$\Delta \delta_{\mathrm{H}}$} \\
\hline & $30^{\circ} \mathrm{C}$ & $52^{\circ} \mathrm{C}$ & $30^{\circ} \mathrm{C}$ & $52^{\circ} \mathrm{C}$ & & \\
\hline & A & B & $\mathrm{C}$ & $\mathrm{D}$ & $\mathrm{C}-\mathrm{A}$ & D-B \\
\hline $2 \mathrm{CH}_{3}$ & $2.02 \mathrm{~m}$ & $2.03 \mathrm{~m}$ & 2.04 & 2.03 & 0.02 & 0.00 \\
\hline $1 \mathrm{Ha}$ & $5.57 \mathrm{brs}$ & $5.57 \mathrm{brs}$ & 5.58 & 5.57 & 0.01 & 0.00 \\
\hline $1 \mathrm{Hb}$ & $5.84 \mathrm{brs}$ & $5.83 \mathrm{brs}$ & 5.85 & 5.85 & 0.01 & 0.02 \\
\hline $5^{\prime} \mathrm{H}$ & $6.98 \mathrm{~d}^{*}$ & $6.98 \mathrm{~d}^{\#}$ & 7.00 & 6.99 & 0.01 & 0.01 \\
\hline $6^{\prime} \mathrm{H}$ & $7.49 \mathrm{dd} * *$ & $7.50 \mathrm{dd}^{\#} \#$ & 7.55 & 7.63 & 0.06 & 0.13 \\
\hline $2^{\prime} \mathrm{H}$ & $7.79 \mathrm{~d} * * *$ & 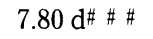 & 7.85 & 7.87 & 0.06 & 0.07 \\
\hline
\end{tabular}

The $\delta_{\mathrm{H}}$ value is ppm downfield from TMSPA as used an external reference in $\mathrm{D}_{2} \mathrm{O}$. Proton Nos: see Fig. 1, $\mathrm{m}$ : multiplet, brs : broad singlet, $\mathrm{d}$ : doublet, dd : double doublet, $*: \mathrm{J}=8$. $6 \mathrm{~Hz}, * *: \mathrm{J}=2.6 \mathrm{~Hz}$ and $8.6 \mathrm{~Hz}, * * *: \mathrm{J}=2.6 \mathrm{~Hz}$, \#: $\mathrm{J}=8.9 \mathrm{~Hz}$, \# $: \mathrm{J}=2.6 \mathrm{~Hz}$ and $\mathrm{J}=8.6 \mathrm{~Hz}$, \# \#\#: $\mathrm{J}=2.6 \mathrm{~Hz}$.

DPPC. This finding was different from that described above in a $\mathrm{D}_{2} \mathrm{O}$ buffer (Table 1 ). This appears to be due to the fact that most of MASA changed to its un-ionized state in $\mathrm{D}_{2} \mathrm{O}$ and, thus, the CONH group of MASA which is a hydrophilic moiety expands in water. Thereby, the $2^{\prime} \mathrm{H}$ and $6^{\prime} \mathrm{H}$ group was located on the surface of the liposomes. 
Table 3 Chemical shift differences $\left(\Delta \delta_{\mathrm{H}}\right)$ between DPPC/MASA (1:1 molar ratio $)$ liposomes in the presence of albumin (or collagen) and DPPC/MASA $(1: 1)$ liposomes in $\mathrm{D}_{2} \mathrm{O}$ buffer solution at $\mathrm{pH} 7.03$.

\begin{tabular}{lccccc}
\hline \multirow{2}{*}{ Proton Nos. } & \multicolumn{2}{c}{ DPPC/MASA liposomes/albumin } & & \multicolumn{2}{c}{ DPPC/MASA liposomes/collagen } \\
\cline { 2 - 3 } \cline { 5 - 6 } & $30^{\circ} \mathrm{C}$ & $52^{\circ} \mathrm{C}$ & & $30^{\circ} \mathrm{C}$ & $52^{\circ} \mathrm{C}$ \\
\hline $2 \mathrm{CH}_{3}$ & 0.01 & 0.00 & & 0.02 & 0.01 \\
$\mathrm{Hla}$ & 0.00 & 0.00 & & 0.02 & 0.01 \\
$\mathrm{Hlb}$ & 0.01 & 0.00 & & 0.02 & 0.01 \\
$5^{\prime} \mathrm{H}$ & 0.01 & 0.01 & & 0.01 & 0.02 \\
$6^{\prime} \mathrm{H}$ & 0.02 & 0.00 & & 0.02 & 0.01 \\
$2^{\prime} \mathrm{H}$ & 0.01 & 0.01 & & 0.01 & 0.01 \\
$\mathrm{x}\left(\mathrm{CH}_{3}\right)_{3}$ & & 0.00 & & & 0.00 \\
$\mathrm{z}$ terminal $\mathrm{CH}_{3}$ & & 0.00 & & & 0.01 \\
$\mathrm{y}\left(\mathrm{CH}_{2}\right)_{14}$ & & 0.00 & & & 0.01 \\
\hline
\end{tabular}

$\Delta \delta_{\mathrm{H}}=\delta_{\mathrm{H}}$ of DPPC/MASA liposomes/albumin (or collagen) $-\delta_{\mathrm{H}}$ of DPPC/MASA liposomes, Proton Nos and alphabets $(x-z)$ : see Fig. 1, and each of an 1.5\% albumin and of $0.1 \%$ collagen was added to DPPC/MASA liposomes.

NMR studies of DPPC / MASA liposomes in the presence of albumin and collagen Monomers containing such substituents as hydroxy and carboxy groups may interact with albumin and cllagen. As shown in Table 3, albumin or collagen was added to the DPPC/ MASA (1: 1 molar ratio) liposomes. Chemical-shift difference values $\left(\Delta \delta_{\mathrm{H}}=\delta_{\mathrm{H}}\right.$ of DPPC/ MASA liposomes/albumin (or collagen) $\delta_{\mathrm{H}}$ of DPPC/MASA liposomes) at $30^{\circ} \mathrm{C}$ and $52^{\circ} \mathrm{C}$ were $0.00-0.02 \mathrm{ppm}$, respectively, indicating that the addition of protein to the liposomes did not significantly alter the chemical shifts of MASA. Within allowances for experimental error $\left(\delta_{\mathrm{H}}: 0.02 \mathrm{ppm}\right)$, the $\Delta \delta_{\mathrm{H}}$ values of the choline $\mathrm{N}$-methyl, the methylene of $\left(\mathrm{CH}_{2}\right)_{14}$ and the terminal methyl group were practically unaltered as compared with DPPC/MASA liposomes (minus $0.01-0.01$ ). The interaction of MASA in lipid bilayers with albumin (or collagen) in $\mathrm{D}_{2}$ $\mathrm{O}$ buffer solution at $\mathrm{pH} 7.03$ was considered small.

DSC studies The phase transition temperature $(\mathrm{Tm})$ and the phase transition profile (H/HHW) of various liposome systems involving DPPC are shown in Table 4. The Tm of DPPC liposomes was $40.5^{\circ} \mathrm{C}$, while that of DPPC / MASA liposomes in the molar ratio of 1 : 1 and $2: 1$ was $36-36.5^{\circ} \mathrm{C}$ with a broadening of the DSC peak $(\mathrm{H} / \mathrm{HHW}=18-20)$. The $\mathrm{Tm}$ of $\mathrm{DPPC}$ induced by MASA shifted lower $4-4.5^{\circ} \mathrm{C}$. The Tm of the various liposome systems in the presence of albumin and collagen are shown in Table 4. The Tm of DPPC / MASA (1: $1)+$ albumin or collagen shifted lower by $1.5^{\circ} 2^{\circ} \mathrm{C}$ as compared with original DPPC/MASA liposomes, but that in the molar ratio of $2: 1$ was unaltered. Since allowance for experimental error in this study was $0.5^{\circ} \mathrm{C}$, the change in the $\mathrm{Tm}$ described above was not large. The $\mathrm{Tm}$ of DPPC liposomes in the presence of proteins was unaltered as compared with that of the original DPPC liposomes. These findings suggest that the interaction of DPPC-MASA was larger than that of MASA-albumin (or collagen) and the interaction between DPPC and protein was small. The $\mathrm{H} / \mathrm{HHW}$ value of DPPC/MASA liposomes reduced in the presence of albumin (or collagen). This indicates that the addition of protein had a relatively large effect on cooperativity of the phase transition of DPPC/MASA liposomes i. e., the surface 
Table 4 Changes in phase transition temperature $(\mathrm{Tm})$ and transition profile value $(\mathrm{H} /$ HHW) of various DPPC-liposome system

\begin{tabular}{|c|c|c|}
\hline Liposome system (molar ratio) & $\begin{array}{c}\mathrm{Tm} \\
{ }^{\circ} \mathrm{C}\end{array}$ & $\mathrm{H} / \mathrm{HHW} \#$ \\
\hline DPPC/MASA $(1: 1)$ & 36.5 & 20 \\
\hline DPPC/MASA $(1: 1)$ & 36 & 20 \\
\hline DPPC/MASA $(1: 1)+$ Albumin & 35 & 7 \\
\hline DPPC/MASA $(1: 1)+$ Albumin & 35.5 & 7 \\
\hline DPPC/MASA $(1: 1)+$ Collagen & 34.5 & 7 \\
\hline DPPC/MASA $(1: 1)+$ Collagen & 35 & 6 \\
\hline DPPC/MASA $(2: 1)$ & 36 & 18 \\
\hline DPPC/MASA $(2: 1)$ & 36.5 & 18 \\
\hline DPPC/MASA $(2: 1)+$ Albumin & 35.5 & 7 \\
\hline DPPC/MASA $(2: 1)+$ Albumin & 36 & 5 \\
\hline DPPC/MASA $(2: 1)+$ Collagen & 36 & 5 \\
\hline DPPC/MASA $(2: 1)$ + Collagen & 36 & 3 \\
\hline DPPC/MASA $(1: 1)^{*}$ & 35 & 24 \\
\hline DPPC/MASA $(1: 1)^{*}$ & 35 & 24 \\
\hline DPPC* & 40.5 & 100 \\
\hline $\mathrm{DPPC}+$ Albumin* & 40 & 94 \\
\hline DPPC + Collagen * & 40.5 & 83 \\
\hline
\end{tabular}

DPPC : dipalmitoylphosphatidylcholine, MASA : N-methacryloyloxy-5-aminosalicylic acid, $\#$ : in $\mathrm{D}_{2} \mathrm{O}$, \#\# : Height/Half-Height Width of DSC main peak (as DPPC liposomes are to 100 ), * : in a $\mathrm{D}_{2} \mathrm{O}$ buffer solution at $\mathrm{pH} 7.03,70 \mathrm{mM} \mathrm{DPPC}$ in a solution, $1.5 \%$ albumin, and $0.1 \%$ collagen.

Table 5 Percentage of hemolysis caused by $\mathrm{N}$-methacryloyloxy-5-aminosalicylic acid (MASA), methyl methacrylate (MMA) and methacryloyloxydecyl dihydrogen phosphate (MDP) at $37^{\circ} \mathrm{C}$

\begin{tabular}{lccc}
\hline Additives* & $\begin{array}{c}\text { Concentration } \\
\mathrm{mM}\end{array}$ & $\begin{array}{c}\text { Reaction time } \\
\min \end{array}$ & $\begin{array}{c}\text { Hemolysis \% } \\
\text { Mean (SD) }\end{array}$ \\
\hline MASA & 19 & 50 & $2.1(0.5)$ \\
MMA & 19 & 50 & $1.0(0.1)$ \\
MDP+ & 19 & 10 & DN \\
\hline
\end{tabular}

An 1\% human erythrocyte in phosphate buffer solution at pH 7.0. DN : Denaturalization of hemoglobin after hemolysis, * : diluted in ethanol and + : diluted in diethylether, and mean (SD) : five samples.

adsorption of protein molecules did partly occur. However, it is clear that the interaction was quite small.

Hemolysis studies Hemolytic activity of MASA, MMA and MDP are shown in Table 5. MASA's degree of hemolysis at $19 \mathrm{mM}$ was $2.1 \%$. That of MDP at $19 \mathrm{mM}$ was not calculated after $10 \mathrm{~min}$ because denaturalization of hemoglobin occurred after strong hemolysis. From this, it was concluded that the hemolytic activity of MASA was markedly weaker than that of MDP, indicating that MDP has stronger surface-active action and has a higher acidity than 
MASA. MMA's degree of hemolysis at $19 \mathrm{mM}$ was $1.0 \%$. Hemolytic activity of MMA increases when it reaches a high concentration (above $100 \mathrm{mM}$ ) due to its low hydrophobicity ${ }^{12)}$. These findings suggest that the biological effect of MASA on pulp is much weaker than that of MDP. The recently reported findings that the biocompatibility of the MASA resin-system is better than that of the $\mathrm{MDP}$-resin system ${ }^{7,8)}$ are also supported by these findings.

\section{CONCLUSIONS}

The $\delta_{\mathrm{H}}$ and $\Delta \delta_{\mathrm{H}}$ of MASA in DPPC/MASA liposomes, with or without the addition of albumin and collagen, in $\mathrm{D}_{2} \mathrm{O}$ buffer solution at $\mathrm{pH} 7.03$ were determined by NMR spectroscopy. The $\Delta \delta_{\mathrm{H}}$ of MASA was unaltered under these conditions. Addition of albumin or collagen to DPPC/MASA liposomes did not have a large effect on the $\mathrm{Tm}$, but did have a relatively large effect on the $\mathrm{H} / \mathrm{HHW}$ value. Hemolytic activity of MASA was markedly smaller than that of MDP. Therefore, using a MASA primer for resin restorations has an acceptable biocompatibility for the dentin-pulp system, involving its adsorption and adhesion to hard tooth tissues.

\section{ACKNOWLEDGMENT}

The authors wish to thank Emeritus Prof. E. MASUHARA, Tokyo Medical and Dental University for supplying MASA.

\section{REFERENCES}

1) Bowen, R. L. : Adhesive bonding of various materials to hard tooth tissues II., Bonding to dentin promoted by a surface-active comonomer, J Dent Res 44 : 895-902, 1965.

2) Masuhara, E.: Über die Chemie einen neuen hafthähigen Kunststoff-Füllungsmaterials, Deutsch zahnarzt 1 Z24: 620-628, 1969.

3) Kojima, K., Tarumi, N., Hotta, H., Nakagawa, K., and Masuhara, E. : Studies of dental self-curing resins (10), Influences of reactive-polymers for adhesive bonding of acrylic resins to hard tooth tissues, Reports of the Institute for Medical and Dental Engineering 2: 44-54, 1968.

4) Hotta, H.: Studies on adhesive filling materials to hard tooth tissues (III), Effects of reactivemonomers and copolymers for adhesion of acrylic resin to hard tooth tissues, J Japan Soc Dent Appar Mat 10:61-69, 1969. (in Japanese)

5) Kojima, K., Iwabuchi, S., Kunagi, M., Kikuchi, J. and Iida, K. : Studies of the polymer ligands (III) : Preparation and copolymerizations of $\mathrm{N}$-methacryloyl aminobenzoic acids and aminosalicylic acids, Journal of faculty of Engineering, Chiba University, 25 (48) : 65-72, 1974. (in Japanese)

6) Tagami, J., Hosoda, H., Imai, Y., and Masuhara, E. : Evaluation of a new adhesive liner as an adhesive promoter and a desensitizer on hypersensitive dentin, Dent Mater $J 6$ (2): 201-208, 1987.

7) Hosoda, H., Inokoshi, S., Fujitani, M., Otsuki, M., and Shimada, Y. : Pulpal response to a new bonding agent and recently designed adhesive liners containing a salicylic acid derivative, Japan $J$ Conserv Dent 32 (2) : 398-410, 1989. (in Japanese)

8) Hosoda, H., and Yamada, T.: A clinical study of a newly developed adhesive resin composite system "Clearfil Liner Bond", A short-term assessment, Japan J Conserv Dent 33 (6) : 1623-1636, 1990. (in Japanese)

9) Fujisawa, S., Kadoma, Y., and Komoda, Y.: Hemolytic mechanism of dental adhesive monomer 
(methacryloyloxydecyl dihydrogen phosphate) using a phosphatidylcholine liposome system as a model for biomembranes, Dent Mater J 9 (2) : 136-146, 1990.

10) Fujisawa, S., Kadoma, Y., and Komoda, Y.: Hemolytic activity of a dental adhesive monomer (4methacryloyloxyethoxycarbonylphthalic anhydride, 4-META) and its interaction with phospholipid liposomes as a determined by NMR and DSC, Dent Mater $J \mathbf{1 0}$ (1), 8-17, 1991.

11) Hauser, H., Pascher, I., Peasons, R. H. and Sundell, S. : Preferred conformation and molecular packing of phosphatidylethanolamine and phosphatidylcholine, Biochem Biophys Acta 65: 21-91, 1981.

12) Fujisawa, S. and Kadoma, Y. : Effect of Bis-GMA analogs on hemolytic activity and DSC phase transition of phospholipid liposomes, J J Dent Mat 6 : 592-599, 1987. (in Japanese) 
歯科用接着性モノマー（N-methacryloyloxy-5-aminosalicylic acid, MASA) の 溶血性及びりん脂質りポソームとの相互作用の NMR, DSC 研究

\author{
藤沢盛一郎*, 菰田泰夫**, 門磨義則** \\ *東京医科菌科大学歯学部総合診断部 \\ **東京医科歯科大学医用器材研究所
}

最近 MASA は接着性プライマーとしてレジン修復シ ステムに用いられている。MASAの生物学的活性をモ ニターするため，アルブミン及びコラーゲン存在下ジパ ルミトイルホスファチジルコリン (DPPC) / MASA リ ポソーム系の NMR ケミカルシフト $\left(\delta_{\mathrm{H}}\right)$ 及び DSC 相転 移温度 $(\mathrm{Tm})$ を研究した。その結果, 蛋白の存在はリポ ソームの $\delta_{\mathrm{H}}$ 及び $\mathrm{Tm}$ に変化を与えなかった。また
MASA とりん脂質 (DPPC) との相互作用も小さいこと が明らかになった。MASAの溶血性はボンデング剤と しては広く用いられているりん酸モノマー(MDP) に比 べ著しく小さかった。以上の所見は MASA プライマー は象牙質一歯髄システムに対して生体適合性があること を示唆した。

\title{
コンポジットレジン修復時に生ずる窩縁部エナメル質微小亀裂に及ぼす 臨床的因子に関する研究 \\ 韓 臨麟, 岡本 明, 岩久正明 \\ 新潟大学歯学部歯科保存学第一教室
}

本研究では, コンポジットレジン修復時に生ずるエナ メル質微小亀裂を, 歯牙表層及び縦断面において, 実体 顕微鏡及び SEM を用いて観察した。さらに, エナメル質 微小亀裂の発生に及ほす臨床的因子, すなわち, 重合方 式，窩縁形態及び研磨時期の影響について検討した。

エナメル質微小亀裂は, ベベルを付与せず充填直後に 研磨を行った 1 級及び 5 級の光重合型コンポジットレジ ン修復物において, 全例に認められた。エナメル質微小
亀裂は, 裔洞辺縁にほほ平行で, 裔洞辺縁より $0.01 \sim 0.3$ $\mathrm{mm}$ 離れた部位に観察された。エナメル質微小亀裂の発 生は,ノン・ベベル墧洞で充填後 10 分あるいは 24 時間 後に研磨を行った群において, 光重合型のほうが化学重 合よりも著しかった。エナメル質微小亀裂の発生は, ベ ベルの付与及び研磨時期を遅らせることにより減少し た。

歯の形状の三次元計測（第 11 報）

—咬合を考慮したクラウン形状設計のための CAD について—

木村 博, 荘村泰治, 高橋純造

大阪大学歯学部歯科理工学講座

$\sqrt{6}$ 臼歯のクラウン補綴のための形状設計の CAD 化に つき研究した。 6 にクラウン用の支台歯形成がされてい る, $5 \sim 7$ 臼歯の石こう模型と, 修復用に用いる 6 完全 歯の計測を行った。

クラウンデータは $\sqrt{6}$ の支台歯に適合し $\sqrt[5]{7}$ の隣接歯と
の調整を行った。その後, $\sqrt{6}$ のデータの座標は 6 支台歯 のそれに変換した。適合したクラウンの端部は, 6 支台 歯の辺縁と結合した。

さらに, 対合歯との咬合関係をFGP 法を応用して調 整した。FGPは,バイトワックスに記録し計測した。 